International Journal of Education and Practice

2021 Vol. 9, No. 3, pp. 487-496.

$\operatorname{ISSN}(e): 2310-3868$

$\operatorname{ISSN}(p): 2311-6897$

DOI: $10.18488 /$ journal.61.2021.93.487.496

(C) 2021 Conscientia Beam. All Rights Reserved.

check for
updates

\title{
TOWARDS A MODEL OF ATTITUDE AND CHARACTER LEARNING THROUGH TRAINING NEEDED BY TEACHERS
}

$\begin{array}{ll}\text { (D) Badeni Badeni }{ }^{1+} & { }^{1,2} \text { Faculty of Teacher Training and Education, Bengkulu University, } \\ \text { ID Sri } & \text { Indonesia. } \\ \text { Saparahayuningsih' } & \text { 'Email: badeni@unib.ac.id } \\ & { }^{2} \text { Email: saparahayu@unib.ac.id }\end{array}$

Emailibadeni@unib.ac.id

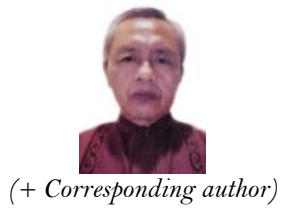

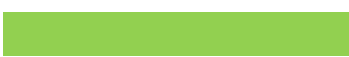

Article History

Received: 2 February 2021 Revised: 5 April 2021

Accepted: 30 April 202

Published: 28 May 202

\section{Keywords}

Attitudes building

Character building

Cognitive level

Skills

Training model

Teachers needs

\begin{abstract}
A number of training models for attitude and character building have been applied to train Indonesian teachers; however, a majority of these teachers still feel confused about how to instill values in their students and shape children's attitudes and characters. Research and development (Kimbrough \& Hutcheson, 1998) model was applied in this study. The sample population of this study consisted of (a) $5 \%$ of the elementary school teachers in Bengkulu Province selected proportionally and randomly, and (b) all the teacher trainers of Bengkulu Province Education Quality Assurance Agency. Data was collected through a Focus Group Discussion (FGD) and inventory instruments. After analyzing data, the researchers concluded: first, training models for attitudes and character building applied so far are only able to improve the cognitive level of teachers and little at the level of understanding, application and analysis; though they have not been able to improve the skills needed by the teacher in shaping the attitudes and character of students. Hence, while providing training to teachers on attitude and character building, it is recommended to use training models that can develop teachers' diligence suiting their needs as well as improve their cognitive abilities.
\end{abstract}

Contribution/Originality: This is a unique research study to discover a character and attitude training model for teachers that can build their attitudes and character and raise their cognitive abilities in order to provide good mentoring services to students.

\section{INTRODUCTION}

Education of values, attitudes, and characters in educational institutions needs to receive a lot of attention, and increase both in intensity and quality. Attitude and character education is a school program that involves collaboration with other community institutions to shape adolescent behavior (White, 2010). Attitude and character education are various interventions from various institutions that directly or indirectly affect a person's values, attitudes, and character development, and the ability to think that a problem or a person's opinion is right or wrong (Lope, 2010). In practice, the mass media, religious communities, cultures, youth, peer groups, volunteer organizations, and especially families, have a significant influence on character building (Arthur, 2005). Character education emphasizes the development of habits and dispositions as prerequisites for moral people (Walker \& Thoma, 2017). Moral education is helping children and adolescents to acquire a set of beliefs and values about what is right and wrong (Hand, 2020). In general, attitude and character education is a process of teaching general 
attitudes, beliefs, and behaviors that are important for people to develop into responsible citizens (Jerome \& Kisby, 2020).

In other words, it can be said that the education of moral values, attitudes, and character, is a learning method that encourages the development of ethical and responsible individuals by teaching good values that humans should have. The main purpose of moral education, attitude, and character education are to form human intelligence to think logically and critically about moral issues, and formulate the actual moral opinion possessed by individuals (Miller, 2014). In this regard, formal educational institutions function as a forum for formal guidance for children and adolescents both in increasing the intensity and quality of education towards values, morals, attitudes, and characters (Badeni, Saparahayuningsih, \& Juarsa, 2017). The Indonesian government welcomes this function by revealing the formation of attitudes, morals, and character of the younger generation as the main goal to be realized in the national curriculum, by choosing a scientific approach (Kemendikbud, 2013). The problem is that even though the government has conducted teacher training with this approach, the level of teacher understanding of authentic assessment is still low. There are still many teachers who have difficulty in implementing character learning, developing assessment instruments, integrating assessment systems, and writing final reports (Carlson \& Heth, 2010). This illustrates that the training model and approach chosen have not had a significant effect on the level of teacher understanding related to these aspects, especially in character learning.

Another problem that occurs is that the learning to utilize the scientific approach has not been fully able to reach the main objectives in the core competencies 1 and 2 in the national curriculum (Badeni \& Saparahayuningsih, 2016). Studies of various theories try to achieve, by way of the scientific learning approach, the educational goals of the expected attitude, moral, and character values, where students have not formed attitudes and characters as desired by the national curriculum.

Based on the findings, it seems that further investigation is needed into (1) how to determine the level of understanding of teachers who are required to choose and implement learning to develop the attitudes and character of students. This learning must take place according to the goals of attitudes and character as prescribed in the national curriculum; (2) what teachers' training needs are required so that teachers can improve the attitude and character of students; (3) training models that consider what should be done by trainers to improve the ability of primary school teachers in selecting and implementing a teaching-learning/instructional system that can develop attitudes and character.

\section{RESEARCH METHODS}

In this study, researchers used Research and Development (R\&D) model developed by Borg and Gall (1983). The sample population of this study consisted of (a) 620 elementary school teachers from nine districts and one city of Bengkulu Province selected proportionally and randomly, and (b) 20 teacher trainers of the Bengkulu Province Education Quality Assurance Agency. Data was collected using the Focus Group Discussion (FGD) techniques and questionnaires. Before employing to collect data, both techniques were validated by experts as an assessment tool through a group discussion forum.

During the FGD, the researchers talked with elementary school teachers and teacher trainers about (1) the level of understanding of the teachers in choosing and implementing learning to develop the attitudes and characters of students in term of attitude and character goals that are expected to innovate the national curriculum; (2) what teachers need from training to be able to develop the attitude and character of students; (3) what training models should be designed by trainers to improve and develop the ability of primary school teachers in selecting and implementing learning models that can develop attitudes and character.

Questionnaires were also arranged in the form of tests and observation checklists to express teachers' understanding of the new curriculum and changes in students' attitudes and character concerning the application of attitude and character training models. The collected data were analyzed descriptively and qualitatively. The 
results of data analysis through the instrument were used as a basis for developing better models for learning attitude training and teacher training in learning attitudes and characters for students.

\section{RESEARCH FINDINGS}

\subsection{FGD Results Data}

Based on the FGD with Bengkulu provincial elementary school teachers, the researchers obtained information about the innovation training received by the teachers. Based on this data, researchers found that $65 \%$ of teachers had received training in the form of lecturing models, $22 \%$ of teachers received IN-ON-IN training and $13 \%$ of teachers were trained using different assistance models. The teachers who had received lecturing model training received information about all the character learning training materials through slideshows and explanations from the trainers. When asked: "Do you think that training received through slideshows and explanations from trainers helped you gain knowledge, understanding, and skills in applying, analyzing teaching processes and also determine the required student learning outcomes?" $88 \%$ of them felt that they only gained general knowledge and a general understanding of all the material being trained but felt confused about how to apply the results of the training in attitude and character building or how to perform the analysis and synthesis of such applications on character building of students. The rest stated that they felt they gained knowledge and understanding of the material presented by trainers, but still felt difficulties about how to apply the results of the training for attitude and character building and how to perform analysis and synthesis of learning processes and its results on students.

The teachers who received IN-ON-IN training revealed that in the training process, the trainer had informed them that they would be given training in the form of three activities, namely IN, ON, and IN. For the first IN activity, the teachers received training for five days in class. During the ON activity, teachers were allowed to apply what they had learned during the first IN at their respective workplaces for three months. At the end of the second month, trainers came in to ask about the implementation difficulties experienced by the teachers in the field (i.e., at their respective workplaces) and explained how to overcome them. For the second IN, after three months, the teachers returned to their training center, where they were instructed to make a report, and present it. When they were asked: "Regarding the training you received, did you feel that you gained knowledge, understanding, and the skills to apply all the material that was fully taught?"

Based on this question (a) $81 \%$ of them responded that they felt they had not gained knowledge, understanding, or ways of application relating to all the material that was taught. They also still felt confused about how to apply learning attitudes and characters to both the learning process and how to evaluate student learning outcomes of attitudes and character. They felt it was more difficult if they had to evaluate, and develop learning according to the competencies they are supposed to achieve. (b) $5 \%$ of them felt they understood and were able to analyze attitude and character learning in the classroom, even though they also experienced difficulties in analyzing and evaluating learning processes and outcomes. The rest stated that they felt they understood but still had difficulties applying character learning in the classroom.

Slightly different data were obtained from teachers who undertook training with the assistance model, in comparison with the teachers who had taken training in the form of the lecturing model and IN-ON-IN method. The teachers who had received attitudes and character learning training with assistance models revealed that they were given brief explanations and training by trainers, then were told to practice in the workplace with one trainer coming to observe the learning process and to direct them. When asked: "Do you feel that you gained full understanding and skills of all the materials that were taught through the training process?" (a) $75 \%$ felt they had not fully gained the knowledge and understanding of the material being taught and that the ability to implement attitudes and character learning were still mechanical, in the sense that the attitudes and character teaching they were doing were still like patterns exemplified by the trainer - both in the learning process and the ways to evaluate the development of children's attitudes and character. 
Furthermore, they still found it very difficult if they were told to analyze and synthesize the learning process and results, evaluate the process and the results of attitudes and character learning on students; (b) $25 \%$ of them felt they understood and that they were able to apply this information to teach attitudes and characters in the classroom, even though, if told to analyze the process and results of attitudes and character learning, they still difficulties. Apart from that, they did not understand how to develop learning models of attitudes and characters that are in line with the core competencies and basic competencies that should be achieved by students.

\subsection{Questionnaire Results from Data}

Two sets of data were obtained from questionnaires; namely, data about teachers' cognitive level of attitudes and character learning and data on the training needs about teachers' character learning. The method used to collect data about the level of understanding of the results of learning attitudes and character training involved adopting the cognitive levels found by Bloom (1956) which was later developed by Anderson and Krathwohl (2001) and Monari (2020). Table 1 illustrates the teachers' ability level concerning the results of the training on learning attitudes and character.

Table-1. The teacher's ability level concerning the results of the training on attitudes and character learning

\begin{tabular}{|c|c|c|c|c|c|c|}
\hline \multirow[b]{2}{*}{$\begin{array}{l}\text { Aspects of Learning Materials Attitude and Character } \\
\text { Training }\end{array}$} & \multicolumn{6}{|c|}{$\begin{array}{l}\text { Percentage of teachers' level of ability } \\
\text { concerning the results of attitude and } \\
\text { character learning training }\end{array}$} \\
\hline & 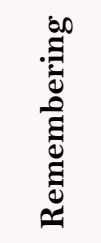 & 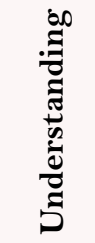 & 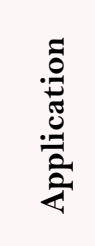 & $\frac{\sqrt[n]{\frac{2}{2}}}{\sum_{2}^{\frac{2}{2}}}$ & 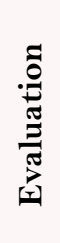 & 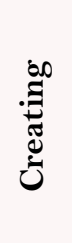 \\
\hline The essence of learning attitude and character & 60 & 30 & 6 & 4 & 0 & $\mathrm{O}$ \\
\hline Theory of learning attitude and character & 65 & 30 & 5 & $\mathrm{O}$ & $\mathrm{O}$ & $\mathrm{O}$ \\
\hline Steps of learning attitude and character & 68 & 25 & 7 & $\mathrm{O}$ & $\mathrm{O}$ & $\mathrm{O}$ \\
\hline Strategy and technique of learning attitude and character & 54 & 37 & 9 & $\mathrm{O}$ & O & $\mathrm{O}$ \\
\hline Preparation of lesson plans for attitude and character & 72 & 20 & 8 & O & O & $\mathrm{O}$ \\
\hline The evaluation system in learning attitudes and characters & 67 & 25 & 8 & $\mathrm{O}$ & $\mathrm{O}$ & $\mathrm{O}$ \\
\hline $\begin{array}{l}\text { Development of attitude and character observation } \\
\text { instruments }\end{array}$ & 66 & 22 & 12 & $\mathrm{O}$ & $\mathrm{O}$ & $\mathrm{O}$ \\
\hline Application of attitude and character learning & 78 & 18 & 4 & $\mathrm{O}$ & $\mathrm{O}$ & $\mathrm{O}$ \\
\hline Average & 66.25 & 25.87 & 7.375 & 0.5 & $\mathrm{O}$ & O \\
\hline
\end{tabular}

Table-2. Percentage of data needed by the teacher in attending attitude and character learning training.

\begin{tabular}{l|c}
\hline Aspects of learning materials attitude and character & $\mathbf{\%}$ \\
\hline The essence of learning attitude and character & 72 \\
\hline Theory of learning attitude and character & 76 \\
\hline Steps for learning attitude and character & 75 \\
\hline Strategies and techniques of learning attitude and character & 78 \\
\hline Preparation of learning plans for attitude and character & 80 \\
\hline The learning system of attitude and character evaluation & 77 \\
\hline Development of instruments for observing attitudes and character & 79 \\
\hline The practice of learning attitudes and character & 78 \\
\hline
\end{tabular}

\section{DISCUSSION}

Based on the results of the FGD with the teachers who were trained using the lecturing model, it was found that $88 \%$ of them felt (a) they only gained general knowledge and understanding from all the material being trained; (b) they were confused about how to apply the results of the training in the implementation of character learning 
throughout the learning process, analysis and synthesis of learning processes and results, evaluating the process and in evaluating the results of character learning on students. The rest (12\%) stated that they (a) felt they gained knowledge and understanding of the material presented by the trainers, but (b) still felt difficulties in applying the results of the training to character learning in the learning process, analysis, and process synthesis and learning outcomes, evaluating the process and evaluating the results of character learning on students.

This means that the implementation of training conducted using lecture models has not met the targets as expected in the training objective. Thus, it can be understood why this model has not been able to effectively achieve the training objectives. Lecturing mainly involves trainees only receiving information on all training material on attitudes and character learning through slideshows and explanation of what is displayed orally from trainers. In this model of training, the trainer does not get the opportunity to engage all the senses of the trainees in full. Out of the five senses, only hearing is engaged, while the senses of sight, motor senses, feelings, sense of smell, taste, and sense of touch (including motion) are less active - if at all.

They also lack feedback on their learning outcomes. This didn't allow trainees to analyze and evaluate their learning outcomes. In the learning process, the more both students and trainees use their senses, the more complete information or knowledge they will receive. The more complete information or knowledge they learn, the more it is possible for them to construct old knowledge and new knowledge into deep and practical knowledge. As Renkl, Atkinson, Maier, and Staley (2002) stated, this deep knowledge will be acquired if learners engage in such higherorder thinking tasks as analysis, synthesis, and evaluation, so they are immersed in experiences of meaning-making inquiry, action, imagination, invention, interaction, hypothesizing and personal reflection; they engage in deliberate practice as promoting practice focused on learning from errors; and they avoid misconceptions constructed by learners (Brown, Roediger, Henry, \& Mcdaniel, 2014; Cranton, 2012).

Besides, training through lecturing models paid little attention to adult characteristics in learning; adult learning must emphasize the benefits of personal training for trainees and the contents that can be applied to the real-life situations of the trainees (Brown et al., 2014). In the process of learning, adults enjoy speaking to one another - not just listening to the sound of the trainer's voice; they also need feedback and constructive criticism; they need training methods that require active participation, provide immediate feedback on practice, either from self-feedback, peer feedback or trainer feedback (Cranton, 2012). It means that adults need course contents that provide them with benefits and can be practiced in their own lives or where they are working. Besides, adult learners want gentle, constructive criticism. Sensitive feedback and constructive criticism that will help trainees correct errors and reinforce good behaviors while providing timely corrective feedback lead to successful learning and mastery of content and skills (Brown et al., 2014; Tolliver, 2010).

In other words, adult learners would acquire deep knowledge or higher abilities and skills to teach students attitude and character, if the adult learners have a lot of opportunities to have close feedback, especially from their trainers, and to speak to each other. Given these opportunities, they will be able to construct their old experiences and their new information or experiences through practicing activities of analyzing, synthesizing, evaluating, and creating a new concept to practice in their workplace.

Based on the results of the interview with trainees trained through IN-ON-IN method, it was found that (a) $81 \%$ of them said they felt that they had not yet received the knowledge, understanding, and full application of all the training material. They also still felt confused about how to apply the learning process of attitudes and character, both concerning the learning process and how to evaluate student learning outcomes. They felt it was more difficult if they had to do an analysis process, evaluation, and development to develop learning according to the competencies they are supposed to achieve. (b) $5 \%$ of them felt they understood and would be able to apply this material to teaching attitudes and characters in the classroom, even though they also experienced difficulties in analyzing, and evaluating learning processes and outcomes of the attitudes and character learning. (c) The rest stated that they felt they understood but still felt difficulties in applying character learning in the classroom. 
Even though the IN-ON-IN model allows trainees to practice the knowledge they obtained in the first IN session at work, they lack the opportunity to receive full guidance or direct feedback when in the field. Guidance or feedback provided by trainers to trainees is only on what they feel has not been understood or issues reported by trainees from their practice in the field. Trainees lack guidance on everything they should know including whether the steps that they are taking in the field are correct or not.

Hence, they also do not know for certain whether they are doing it correctly or not. As a result, trainees have doubts about carrying out their duties in the field. In connection with this, it is not surprising that trainees still feel confused about how to apply learning attitudes and characters to both the learning process and how to evaluate student learning outcomes. They feel more difficult if they have to do an analysis process, evaluation and must develop learning according to the competencies they are supposed to achieve. This is because even though they get guidance during practice in the field $(\mathrm{ON})$, the guidance they receive is only based on what they report to the trainers when they are present. When trainers visit trainees in the field, they rarely observe what trainees are doing/practicing in the field (in class), so that trainers do not fully understand whether the trainees have mastered both theoretically and practically what should be done in the field. As a result, the trainers only resolve the problems reported by the trainees, and the suggestions they offer might not be valid as the trainers would not be fully informed of what has or has not been mastered by the trainees, both conceptually and practically.

This is in line with what was said by Vygotsky (1978); Carlson and Heth (2010) stated that seeing objects as perceived within an environment according to all of their elements taken together is a global construct. In other words, the whole is something other than the sum of its parts. Vygotsky (1978) elucidated the relationship between cognitive processes and social activities and led to the sociocultural theory of development, which suggests that learning takes place when students solve problems. Carlson and Heth (2010) also said: "that our brain is capable of generating whole forms, especially for the visual recognition of global figures instead of just collections of simpler and unrelated elements." All this means that trainees will gain understanding and skills in full if they gain experience and guidance from the trainer as a whole, thus improving both the understanding gained through the brain structure and the ability to practice in the field according to the situation.

Through interviews, the teachers who received training with assistance models revealed that they were given brief explanations and training by trainers, then told to practice in the workplace with a trainer coming to observe the learning process and to give them directions. When asked: "Did you feel that you gained the understanding and skills of all the materials that are fully trained through the training process?" The majority of trainees (75\%) felt they knew what they were being taught but had not yet fully gained the knowledge and understanding of the material they were taught while their ability to carry out learning attitudes and character was still mechanical in the sense that the teaching of attitudes and character, they were still like patterns exemplified by the trainer, both in the learning process and ways to evaluate the development of children's attitudes and character.

The trainees also found it very difficult to analyze and synthesize learning processes and results, or evaluate the process and the results of character learning on students. Only a small number of trainees (25\%) felt they understood and would be able to apply this knowledge to teach students attitudes and character in the classroom, although they still experienced difficulties when told to analyze the process and results of learning attitudes and characters from the learning process they were applying. Apart from that, they did not understand how to develop learning models of attitudes and characters that are in line with the core competencies and the basic competencies that should be achieved.

This happened because, during the training process, the trainers only gave examples, while the trainees were only told to practice what was exemplified by the trainer. This means that the training process only occurred mechanically. As the trainees only had the opportunity to practice mechanically the acquired abilities occurred only mechanically, exactly as exemplified by the trainer. This means trainees gain less experience in exploring what they 
are learning. A further consequence of this is that when they are faced with problems and are in different situations and conditions, they experience confusion.

Learning will succeed if the trainee experiences it in full through cognitive and sensory processes. In the cognitive process, learning is achieved if the trainee experiences the use of the power of thinking (higher-order thinking) by always answering questions commonly called $5 \mathrm{~W}+1 \mathrm{H}$ (What, Why, Who, When, Where, and How). When learning in this way, trainees always concentrate on answering these questions - what trainees are learning, why trainees should be like this, how to do it, who can or should carry it out, where it is done and when it is done.

In terms of sensory learning, a person will succeed if he uses all his senses. The more trainees use all the senses they have, the better the level of learning results will be. In the process of learning, trainees must not only use their sense of hearing but training should also allow them to use all their senses (hearing, sight, taste, motion, and smell). This is in line with what was theorized by Dale (1969). He mentioned, "that learners retain more information by what they 'do 'as opposed to what is 'heard', 'read' or 'observed'". He also said all sensory organs must be awakened or activated to receive memory, understanding, and skills as they are pursued. Edgar Dale studied information retention and arranged a model. His model of the most dramatic amount of retention, retaining $90 \%$ of the information, comes through what we say and do. This occurs when we are actively doing, saying, or experiencing (NC State University, 2018). The more concrete the students are learning, the more students are actively involved; the more abstract, and the less they are involved means less cognitive and affective learning.

It can be concluded that a training process will produce the best results if trainees have the opportunity to learn in a way that enables them to be actively involved in cognitive, affective, psychomotor processes and gain luck in the learning process.

Findings have revealed the average level of mastery/cognitive ability of teachers concerning attitude and character training materials (Table 1). The average cognitive level of the teachers concerning attitude learning material and character were $66.25 \%$ at the level of remembering; $25.87 \%$ for the level of understanding (understanding); $7.375 \%$ for the level of application (application), and the analysis level was 0.5\%. The level of evaluation (evaluation) and creation (creating) was at $0 \%$. The data illustrates that the cognitive level of the majority of teachers concerning the character learning outcomes was still at a low level, namely at the level of remembering (remembering), and, at a higher cognitive level, mastery was even lower; while no teachers had a cognitive level at the level of evaluation (evaluation) or creation of the attitudes and character training results. This means that these curriculum innovation training models (lecturing models, IN-ON-IN models, and assistance models) are not appropriate ways a teacher should receive training. This is because the training models are designed based on the training objectives and targets desired by the trainers, not the needs of the trainees and how trainees who are adults learn.

The training should be carried out by the four principles put forward by Knowles (1984); Kearsley (2010) and Bandura (1977), namely that (1) trainees should be involved in the planning and evaluation process relating to their learning (2) learning material should be based on the needs and elevation of the world of work; (3) trainees should be actively involved in the learning process; and (4) trainees should be oriented to the problems they might face rather than training material. Relating to the fourth application, Kearsley (2010) explained that training should (1) be carried out by explaining why something needs to be learned; (2) explain the relevance of training to the needs of the world of work; (3) pay attention to the needs and level of needs of the trainees; (4) provide trainees with total direct feedback in practice in the field; and (5) provide opportunities for trainees to become actively involved in the learning process. This last principle agrees with Brame (2016) that, in the learning process, it is necessary to apply an active learning approach, namely learning that better trains the trainees' skills or demands that trainees do something, provide high-level thinking and thinking rather than transmitting the information. 
The lack of compliance with the training models (lecturing model, IN-ON-IN model, and assistance model) is in line with the questionnaire data on the level of teachers' need for attitude and character learning training material, where the average teacher's need for training material on attitude and character learning was $77.5 \%$. This means that the current training models used to improve the teacher's ability to conduct attitude and character learning (lecturing model, IN-ON-IN model, and assistance model) need to be replaced with a training model that meets the principles of adult training, that is capable of improving the cognitive level and ability of teachers following the level of teachers' needs in the field. In other words, a model of attitudes and character learning training for teachers will be effective and will fulfill the needs of teachers if the used training model is relevant to the principles of adult learning in the form of the following model as in Figure 1.

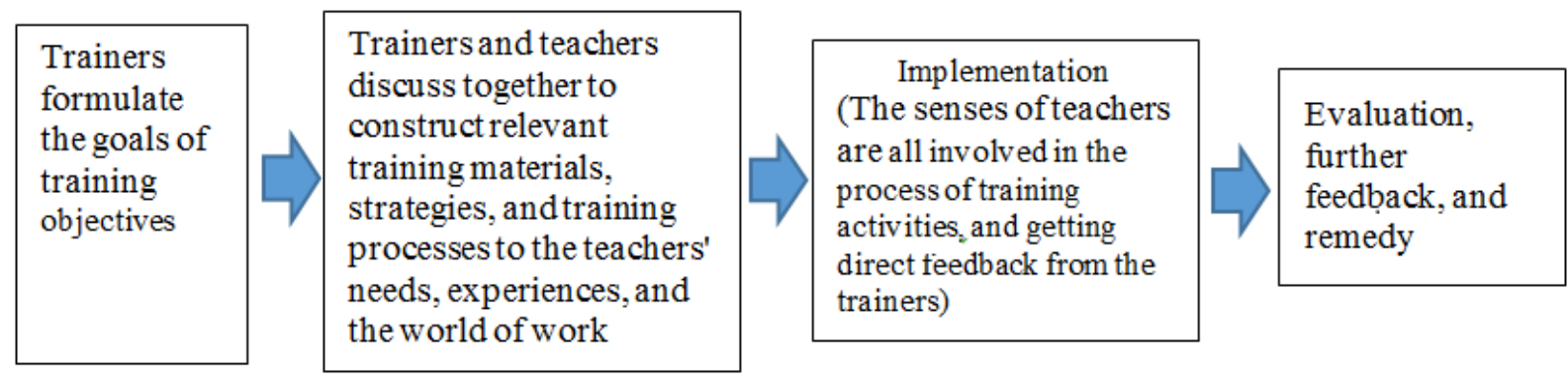

Figure-1. A model of attitudes and character learning training needed by teachers

\section{CONCLUSION}

The study showed that attitude and character learning training done in the form of lecturing, IN-ON-IN and assistance models (a) can only improve the cognitive level of teachers in learning attitudes and characters at a low level, namely at the level of remembering and at least at the level of understanding, application, and analysis; (b) have not been able to improve the cognitive level of teachers at the level of evaluation and creation; (c) have not been able to improve the skills needed by teachers in shaping the attitudes and character of students. Moreover, the learning model of attitudes and character learning needed by teachers is a training model (a) that can improve the ability of teachers, according to their needs or by getting them to think at a higher level (b) in the form of IN - ON (clinical supervision) - IN by always challenging them to answer $5 \mathrm{~W}+1 \mathrm{H}$ questions, and to complete mentoring as they practice in the field will allow teachers to have cognitive abilities from the low to the highest level (understand, apply, analyze, evaluate and create) about the learning attitudes and character of students. These cognitive abilities include nature, theory, steps, strategies and techniques, preparation of learning plans, evaluation systems, development of observation instruments, and application of learning attitudes and character.

\section{RECOMMENDATIONS}

The application of the attitude and character learning process to the teacher should apply andragogy training. Therefore, the trainer for the teacher should not only apply one of the models that have been used so far (the lecture model, the IN-ON-IN model, and the assistance model) but also have to adapt whichever model is used with the situations, conditions, and learning objectives where the training will be implemented. During the training, the attitude and character learning trainer must pay attention to the characteristics of adult learning, especially the material that must be adjusted to the level of the needs of the training participants' work world, carried out collegially (not being taught), include complete mentoring, and encourage them to think rationally by applying $5 \mathrm{~W}$ $+1 \mathrm{H}$.

Funding: This study received financial support from the Indonesian Ministry of Education and Culture.

Competing Interests: The authors declare that they have no competing interests.

Acknowledgement: All authors contributed equally to the conception and design of the study. 


\section{REFERENCES}

Anderson, L. W., \& Krathwohl, D. R. (2001). A taxonomy for learning, teaching, and assessing: A revision of bloom's taxonomy of educational objectives (A Bridged ed.). New York: Addison Wesley Longman, Inc.

Arthur, J. (2005). The re-emergence of character education in british education policy. British Journal of Educational Studies, 53(3), 239-254. Available at: https://doi.org/10.1111/j.1467-8527.2005.00293.x.

Badeni, \& Saparahayuningsih, S. (2016). An attitude and character instructional development based on curriculum 2013 in elementary school. Creative Education, 7, 269-277. Available at: 10.4236/ce.2016.72025.

Badeni, Saparahayuningsih, S., \& Juarsa, O. (2017). Development of attitudes and character educational model based on the 2013 SLTP curriculum in bengkulu province. Research Report: The Research Institute and Community Service Of Bengkulu University.

Bandura, A. (1977). Social learning theory. New York: General Learning Press.

Bloom, B. S. (1956). Taxonomy of educational objectives, handbook: The cognitive domain. New York: David McKay.

Borg, W. R., \& Gall, M. D. (1983). Educational research. An introduction. New York: Longman Inc.

Brame, C. (2016). Active iearning. Vanderbilt University Center for Teaching. Retrieved [todaysdate] from: https://cft.vanderbilt.edu/active-learning/.

Brown, P. C., Roediger, I., Henry, L., \& Mcdaniel, M. A. (2014). Make It Stick: The science of successful learning. Cambridge, Massachusetts, London, England: The Belknap Press Of Harvard University Press.

Carlson, N. R., \& Heth, C. D. (2010). Psychology the science of behavior (7th ed., pp. 20-22). Ontario, CA: Pearson Education Canada.

Cranton, P. (2012). Planning instruction for adult learners (3rd ed.). Toronto: Wall \& Emerson.

Dale, E. (1969). Audio-visual methods in teaching. New York: The Dryden Press.

Hand, M. (2020). Symposium on Michael Hand's A theory of moral education. Journal of Beliefs \& Values, 41(2), $227-228$. Available at: http://doi.org/10.1080/13617672.2020.1717222.

Jerome, L., \& Kisby, B. (2020). Lessons in character education: Incorporating neoliberal learning in classroom resources. Critical Studies in Education, 1-16. Available at: 10.1080/17508487.2020.1733037.

Kearsley, G. (2010). Andragogy (M.Knowles). The theory Into practice database. Retrieved from: http://tip.psychology.org. Kemendikbud. (2013). Teacher training materials implementation of the 2013 curriculum for the 2013 curriculum of social sciences middle school, BPSDMP and PMP Kemendikbud 2013. Retrieved from https://www.kemdikbud.go.id/kemdikbud/dokumen/PTerbang/Exposure\%20Wamendik.pdf.

Kimbrough, W. M., \& Hutcheson, P. A. (1998). The impact of membership in Black Greek-letter organizations on Black students' involvement in collegiate activities and their development of leadership skills. Journal of Negro Education, 67(2), 96-105. Available at: https://doi.org/10.2307/2668220.

Knowles, M. (1984). Andragogy in action. San Francisco: Jossey-Bass.

Lope, D. (2010). A critical analysis of values clarification. Montgomery (USA): Apologetics Press, Inc.

Miller, M. (2014). Teaching and learning in affective domain. In M. Orey (Ed.), Emerging perspectives on learning, teaching, and technology. Retrieved from http://epltt.coe.uga.edu/. [Accessed 8 September 2014].

Monari, J. M. (2020). Higher-order questions for higher order thinking skills. International Journal of Education and Research, 8, 18.

NC State University. (2018). Edgar Dale's cone of experience. Retrieved from: https://content.ces.ncsu.edu/. [Accessed October $18,2005]$.

Renkl, A., Atkinson, R. K., Maier, U. H., \& Staley, R. (2002). From example study to problem solving: Smooth transitions help learning. The Journal of Experimental Education, 7O(4), 293-315. Available at: https://doi.org/10.1080/00220970209599510.

Tolliver, D. E. (2010). Using an African-centered paradigm for understanding race and racism in adult education In Sheared, $V$., Johnson-Bailey, J., Colin III S. A. J., Peterson, E., Brookfield, S.D., (Eds.), Cunningham P.M. (foreword), The Handbook of 
Race and Adult Education: A Resource for Dialogue on Racism (Jossey-Bass Higher Education Series). San Francisco: JosseyBass A Wiley Imprint.

Vygotsky, L. S. (1978). Mind in society. Cambridge, MA Harvard University Press.

Walker, D. I., \& Thoma, S. (2017). Moral and character education. Retrieved from: https://doi.org/10.1093/acrefore/9780190264093.013.119.

White, R. M. (2010). Building schools of character: The development, implementation, and evaluation of school-based character education programme designed to promote cooperative learning and reduce anti-social behavior. Durham Theses, Durham University. Available at Durham E-Theses. 